\title{
Performance of Maize Landrace under No-till as Affected by the Organic and Mineral Fertilizers
}

\author{
Eduardo Fávero Caires*, Helio Antonio Wood Joris, Susana Churka and Renato Zardo \\ Filho
}

Universidade Estadual de Ponta Grossa; Av. Gal. Carlos Cavalcanti 4748; 84030-900; Ponta Grossa - PR - Brasil

\begin{abstract}
The aim of this work was to study the effects of organic and mineral fertilizers at sowing (without fertilizers, organic poultry litter fertilizer on the surface and mineral $\mathrm{NK}+$ reactive natural phosphate from Arad and NK + triple superphosphate in the furrow) and topdressing (without fertilizers, organic poultry litter fertilization and urea) on chemical attributes of a no-till Oxisol and nutrition and yield of maize landrace (Zea mays L.), Carioca variety in a field experiment. Results revealed that $P$ content (Mehlich 1 and resin) was increased in the soil surface layer with organic poultry litter fertilizer on the surface at sowing. Mineral fertilizer in the sowing furrow could be replaced by organic fertilizer with poultry litter on the surface, but topdressing fertilization with urea resulted better $N$ nutrition for the plants and higher grains yield than the organic poultry litter fertilization.
\end{abstract}

Key words: Zea mays, reactive natural phosphate, nitrogen fertilization, poultry litter

\section{INTRODUCTION}

No-till systems are as one of the most effective strategies to improve the sustainability of farming system in the tropical and subtropical regions by reducing soil and nutrient losses through erosion (Lal 1995; Hobbs et al. 2008). The growth of the area under no-till has been especially rapid in South America where some countries such as Argentina, Brazil, Paraguay, and Uruguay are using this system on about $70 \%$ of the total cultivated agricultural area (Derpsch and Friedrich 2009). In Brazil, the cultivated agricultural area under no-till has rapidly increased to 25.5 million hectares (Derpsch and Friedrich 2009), including the areas in which conventional crop management systems and natural pasture grazing by the cattle are common.
With the evolution of agriculture, many advances related to the crop management and the development of genotypes with high productive potential adapted to different environments have been achieved. Because the search for higher grain yield originated great changes in relation to the genetic interaction with management techniques, over the years, maize crop is often regarded as a kind of technological development model.

Landraces have been gradually substituted by maize hybrids with higher productive potential, which resulted in genetic erosion of maize landraces (Paterniani 1980). Despite being less productive than the maize hybrid varieties, the landraces present high potential of adaptation to soil-climate conditions, lower cost to obtain the seeds and high crop potential to attend market niches (Paterniani et al. 2000; Pinto et al. 2009). However, very little information is known about

*Author for correspondence: efcaires@uepg.br 
their nutritional demands for agronomic adaptation to different crop environments.

Fertilizers cost in Brazil has contributed significantly to the reduction of crop profits. Organic fertilizers might become a viable alternative for the maize landrace production by small farmers, considering the high cost of mineral fertilizers and the possibility of aggregating value to the product through quality improvement.

Poultry litter is one of the best organic fertilizers available for agriculture uses as it shows the ability to increase the organic matter and supply, mainly, nitrogen $(\mathrm{N})$ and phosphorus $(\mathrm{P})$ to the plants (Moore et al. 1995; Endale et al. 2008; Yadvinder-Singh et al. 2009). Reactive rock phosphates (sedimentary rocks) might also be an interesting option for small farmers in replacement to the totally acidulated phosphates, as they usually represent lower cost per P unit. They are usually less soluble in water and effective within specific conditions of soil management, such as high organic matter and clay content acid soils, with high $\mathrm{P}$ adsorption capability (Chien and Menon 1995; Prochnow et al. 2006; Pauletti et al. 2010).

Despite increasing interest in substituting the mineral fertilizers by organic fertilizers and fast growth of no-till crop areas in Brazil, effects of organic fertilizers on the surface, both in sowing and topdressing, aiming at replacing or complementing mineral fertilization in maize crops are unknown. This work examined the effects of organic and mineral fertilizers at sowing and topdressing on soil chemical attributes and grain yield of maize landrace crop under a no-till system.

\section{MATERIALS AND METHODS}

The experiment was carried out at Ponta Grossa, Paraná State, Brazil $\left(25^{\circ} 10^{\prime} \mathrm{S}, 50^{\circ} 05^{\prime} \mathrm{W}\right)$, on a loamy Typic Hapludox under a no-till system for eight years. Table 1 shows the soil chemical analyses results, layers $0-10$ to $10-20 \mathrm{~cm}$, carried out before the beginning of the experiment. A randomized complete block design was used, with three replications in a $4 \times 3$ factorial arrangement. The $38.4 \mathrm{~m}^{2}(6.4 \times 6.0 \mathrm{~m})$ plots received four treatments of fertilizers at sowing: no fertilization, organic fertilization, $\mathrm{NK}+$ reactive natural phosphate from Arad (RNF) and NPK mineral fertilization, as well as three treatments of topdressing fertilization: no fertilization, organic fertilization and nitrogen mineral fertilization. Based on the results of the soil chemical analyses and the maize nutritional demands, $30 \mathrm{~kg} \mathrm{ha}^{-1}$ of $\mathrm{N}, 60 \mathrm{~kg} \mathrm{ha}^{-1}$ of $\mathrm{P}_{2} \mathrm{O}_{5}$ and $45 \mathrm{~kg} \mathrm{ha}^{-1}$ of $\mathrm{K}_{2} \mathrm{O}$ were applied at sowing and $120 \mathrm{~kg} \mathrm{ha}^{-1}$ of $\mathrm{N}$ at topdressing.

Organic fertilization at sowing and topdressing was carried out by applying the poultry litter on the soil surface at 10 and $5 \mathrm{t} \mathrm{ha}^{-1}$ respectively, based on dry weight and organic fertilizer nutrients (Table 2). The rates of poultry litter used at sowing and topdressing were calculated from the maize crop need of $\mathrm{N}$, considering about 50\% mineralization (CQFS - RS/SC, 1997) of the total $\mathrm{N}$ found in the compound. Nitrogen, $\mathrm{P}$, and $\mathrm{K}$ mineral sources used were urea, triple superphosphate (TSP) and potassium chloride $(\mathrm{KCl})$, respectively. The topdressing fertilization was carried out at the vegetative stage $\mathrm{V}_{4}$.

Table 1 - Soil chemical attributes at 0-10 and 10-20 cm depths, before the establishment of the experiment.

\begin{tabular}{ccccccccc}
\hline Depth & $\mathbf{p H}\left(\mathbf{C a C l}_{\mathbf{2}}\right)$ & $\mathbf{A l}^{\mathbf{3 +}}$ & $\mathbf{H}+\mathbf{A l}$ & $\mathbf{C a}^{\mathbf{2 +}}$ & $\mathbf{M g}^{\mathbf{2 +}}$ & $\mathbf{K}^{+}$ & $\mathbf{P}(\mathbf{M e h l i c h ~ 1 )}$ & Organic-C \\
\hline $\mathrm{cm}$ & & ------------ & $\mathrm{mmol}_{(+)} \mathrm{dm}^{-3}$ & ------------ & $\mathrm{mg} \mathrm{dm}^{-3}$ & $\mathrm{~g} \mathrm{dm}^{-3}$ \\
$0-10$ & 5.1 & 0.0 & 53.5 & 28 & 17 & 2.9 & 12.8 & 28 \\
$10-20$ & 5.1 & 0.0 & 53.5 & 24 & 16 & 1.7 & 2.6 & 18 \\
\hline
\end{tabular}

Table 2 - Characteristics of poultry litter used in the study.

\begin{tabular}{cccccc}
\hline Water content & Organic-C & N & $\mathbf{P}$ & \multicolumn{1}{c}{ K } & C/N ratio \\
\hline- & - & $\mathrm{g} \mathrm{kg}^{-1}$ & - & & \\
389.4 & 194.1 & 16.3 & 11.4 & 16.7 & 11.9 \\
\hline
\end{tabular}

Analysis performed according to the methods described by Kiehl (1985). 
The maize (Zea mays L.), variety Carioca, was sowed in November 2006, after black oat (Avena strigosa Schreb) growth at a seeding rate of 6 seeds $/ \mathrm{m}$, and row spacing of $0.80 \mathrm{~m}$. The landrace Carioca presented dent grains and high potential of response to fertilization when compared to other varieties (Machado et al. 1999). Seasonal rainfall and air temperature data for the period 2006-07 when the maize crop was in the field are shown in Figure 1. Throughout the development period of the crop, weather conditions were normal and there was no water limitation.

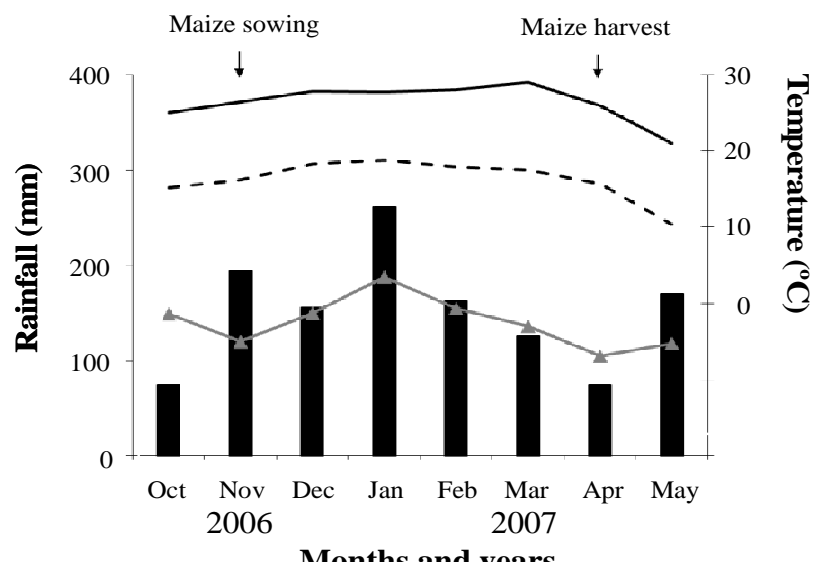

Figure 1 - Monthly rainfall (vertical bars) and minimum (-- ) and maximum (-) temperatures during the maize crop development period, and 45 years average monthly rainfall $(-\leftarrow)$ at Ponta Grossa, southern Brazil.

Samples of leaves were collected at the beginning of the maize crop flowering. The leaf under and opposite to the ear was picked from 30 plants in each plot. Chlorophyll content was measured in the leaves collected, with ten readings of the central part of each leaf, using a Minolta SPAD502 chlorophyllometer. After that, the leaves samples were washed with deionized water, the leaves ends were cut out and the veins removed.

The leaves samples that contained the mid-third without veins were dried in a forced-air oven at $60{ }^{\circ} \mathrm{C}$ until constant mass was achieved and ground. Nitrogen, $\mathrm{P}$, and $\mathrm{K}$ contents were determined according to the methods described by Malavolta et al. (1997).

Ten plants from each plot were used for measurement of culm diameter and height carried out at the flowering peak. Culm diameter was measured with a pachymeter and the plants height with a ruler, from the plant base to the last culm node. At the same time, ten plants were randomly removed from each plot. Plants collected were then washed with deionized water and dried in oven with forced air circulation at $60{ }^{\circ} \mathrm{C}$ until the constant mass was obtained. After dry matter production evaluation, the plants were ground and after that $\mathrm{N}, \mathrm{P}$ and $\mathrm{K}$ contents were determined according to Malavolta et al. (1997). Extraction of
$\mathrm{N}$, P, and $\mathrm{K}$ by the maize plants was calculated by multiplying the dry matter production by the nutrients concentration in the shoot.

Maize grain yield was evaluated after the physiological maturation of the crop through handpicking and threshing with a stationary thresher. The four central rows of each plot were harvested, discharging $1 \mathrm{~m}$ of each end $\left(12.8 \mathrm{~m}^{2}\right)$. Grain yields were corrected to $130 \mathrm{~g} \mathrm{~kg}^{-1}$ moisture content. While harvesting, the total number of plants was counted as well as the number of lodged plants within the area $\left(12.8 \mathrm{~m}^{2}\right)$ used for the calculation of lodging percentage.

Soil samples were taken as soon as maize was harvested. To obtain a composite sample, five soil cores (two from each inter row and one from the sowing row) were taken from three different locations in each plot at 0-5, 5-10 and 10-20 cm depth using a soil probe. Organic carbon content was determined through the Walkley-Black method. Exchangeable $\mathrm{K}^{+}$was extracted with Mehlich 1 solution (Pavan et al. 1992) and $P$ with Mehlich 1 solution (Pavan et al. 1992) and anionic exchange resin (Raij et al. 2001).

Results were submitted to the analysis of variance, following a randomized complete block design in a factorial arrangement model. Treatment effects were compared by the Tukey test at $p=0.05$. 


\section{RESULTS AND DISCUSSION}

Variance analysis of the chemical analyses of soil did not reveal a significant interaction between the fertilization treatments at sowing and topdressing. The organic $\mathrm{C}$ and exchangeable $\mathrm{K}^{+}$contents, at different soil depths were not influenced by the organic or mineral fertilization at sowing or topdressing (Table 3). Soil P content extracted with Mehlich 1 solution or resin was significantly higher at the soil surface layer $(0-5 \mathrm{~cm})$ when organic fertilization at sowing was applied, when compared with the treatments without fertilization or with NK + RNF and NK + TSP fertilization.

Table 3 - Contents of organic C, exchangeable $\mathrm{K}$, and available $\mathrm{P}$ in the soil as affected by the fertilizer treatments at sowing and topdressing for growing the maize landrace under a no-till system.

\begin{tabular}{|c|c|c|c|c|}
\hline \multirow{2}{*}{ Treatment } & \multirow{2}{*}{ Organic-C } & \multirow{2}{*}{$\mathbf{K}^{+}$} & \multicolumn{2}{|c|}{$\mathbf{P}$} \\
\hline & & & Mehlich 1 & Resin \\
\hline & $\mathrm{g} \mathrm{dm}^{-3}$ & $\mathrm{mmol}_{(+)} \mathrm{dm}^{-5}$ & --------1 & --------- \\
\hline & \multicolumn{4}{|c|}{$0-5 \mathrm{~cm}$} \\
\hline \multicolumn{5}{|l|}{ Sowing fertilizer } \\
\hline No fertilizer & $22.9 \mathrm{a}$ & $4.8 \mathrm{a}$ & $18.1 \mathrm{~b}$ & $22.6 \mathrm{~b}$ \\
\hline Poultry litter & $23.2 \mathrm{a}$ & $5.6 \mathrm{a}$ & $38.5 \mathrm{a}$ & $34.8 \mathrm{a}$ \\
\hline NK + Arad Phosphate Rock & $22.2 \mathrm{a}$ & $4.7 \mathrm{a}$ & $18.5 \mathrm{~b}$ & $21.1 \mathrm{~b}$ \\
\hline NK + Triple Superphosphate & $22.3 \mathrm{a}$ & $4.8 \mathrm{a}$ & $17.4 \mathrm{~b}$ & $20.5 \mathrm{~b}$ \\
\hline \multicolumn{5}{|l|}{ Topdressing fertilizer } \\
\hline No fertilizer & $21.9 \mathrm{a}$ & $5.1 \mathrm{a}$ & $23.2 \mathrm{a}$ & $21.1 \mathrm{~b}$ \\
\hline Poultry litter & $22.8 \mathrm{a}$ & $4.9 \mathrm{a}$ & $22.4 \mathrm{a}$ & $28.1 \mathrm{a}$ \\
\hline Urea & $23.2 \mathrm{a}$ & $5.0 \mathrm{a}$ & $23.9 \mathrm{a}$ & $25.0 \mathrm{ab}$ \\
\hline \multirow[t]{2}{*}{$\mathrm{CV}(\%)$} & 7.2 & 15.4 & 31.1 & 21.0 \\
\hline & \multicolumn{4}{|c|}{$0-10 \mathrm{~cm}$} \\
\hline \multicolumn{5}{|l|}{ Sowing fertilizer } \\
\hline No fertilizer & $19.5 \mathrm{a}$ & $3.7 \mathrm{a}$ & $17.5 \mathrm{a}$ & $17.9 \mathrm{bc}$ \\
\hline Poultry litter & $20.5 \mathrm{a}$ & $4.2 \mathrm{a}$ & $22.8 \mathrm{a}$ & $24.3 \mathrm{a}$ \\
\hline NK + Arad Phosphate Rock & $20.4 \mathrm{a}$ & $3.6 \mathrm{a}$ & $15.5 \mathrm{a}$ & $15.4 \mathrm{c}$ \\
\hline $\begin{array}{l}\text { NK + Triple Superphosphate } \\
\text { Topdressing fertilizer }\end{array}$ & $20.6 \mathrm{a}$ & $3.9 \mathrm{a}$ & $18.7 \mathrm{a}$ & $21.0 \mathrm{ab}$ \\
\hline No fertilizer & $20.4 \mathrm{a}$ & $3.8 \mathrm{a}$ & $17.9 \mathrm{a}$ & $19.3 \mathrm{a}$ \\
\hline Poultry litter & $20.0 \mathrm{a}$ & $3.9 \mathrm{a}$ & $18.4 \mathrm{a}$ & $19.6 \mathrm{a}$ \\
\hline Urea & $20.3 \mathrm{a}$ & $3.8 \mathrm{a}$ & $19.6 \mathrm{a}$ & $20.1 \mathrm{a}$ \\
\hline \multirow[t]{2}{*}{$\mathrm{CV}(\%)$} & 9.4 & 13.1 & 30.4 & 18.5 \\
\hline & \multicolumn{4}{|c|}{$0-20 \mathrm{~cm}$} \\
\hline \multicolumn{5}{|l|}{ Sowing fertilizer } \\
\hline No fertilizer & $19.1 \mathrm{a}$ & $2.6 \mathrm{a}$ & $9.5 \mathrm{a}$ & $11.9 \mathrm{~b}$ \\
\hline Poultry litter & $18.7 \mathrm{a}$ & $3.1 \mathrm{a}$ & $10.2 \mathrm{a}$ & $14.9 \mathrm{a}$ \\
\hline NK + Arad Phosphate Rock & $19.0 \mathrm{a}$ & $2.6 \mathrm{a}$ & $7.4 \mathrm{a}$ & $10.2 \mathrm{~b}$ \\
\hline $\begin{array}{l}\text { NK + Triple Superphosphate } \\
\text { Topdressing fertilizer }\end{array}$ & $18.8 \mathrm{a}$ & $2.7 \mathrm{a}$ & $6.9 \mathrm{a}$ & $9.6 \mathrm{~b}$ \\
\hline No fertilizer & $18.9 \mathrm{a}$ & $2.9 \mathrm{a}$ & $8.1 \mathrm{a}$ & $9.9 \mathrm{a}$ \\
\hline Poultry litter & $18.5 \mathrm{a}$ & $2.8 \mathrm{a}$ & $9.1 \mathrm{a}$ & $11.5 \mathrm{a}$ \\
\hline Urea & $19.2 \mathrm{a}$ & $2.6 \mathrm{a}$ & $8.4 \mathrm{a}$ & $13.6 \mathrm{a}$ \\
\hline $\mathrm{CV}(\%)$ & 7.5 & 16.3 & 34.8 & 25.0 \\
\hline
\end{tabular}

Same letters in the columns do not differ significantly by Tukey test at $p=0.05$. 
Anionic exchange resin presented higher sensitiveness than Mehlich 1 solution to detect the increase in soil $\mathrm{P}$ at $0-10$ and $0-20 \mathrm{~cm}$ depths, with organic fertilization at sowing, and also at 0 $5 \mathrm{~cm}$ depth, with topdressing organic fertilization. Soil P-resin content at $0-10 \mathrm{~cm}$ depth was similar with the use of organic fertilization or NK + TSP at sowing. However, the higher increase in soil $\mathrm{P}$ was obtained with the addition of poultry litter on the soil surface at sowing. According to the available $\mathrm{P}$ found in the soil, compared to the control treatment, it could be observed that there was high $\mathrm{P}$ mineralization added by the poultry litter. Besides, due to the presence of calcium and magnesium phosphates and the formation of precipitates in the poultry litter (Fordham and Schwertmann 1977), continuous $P$ release occurs during the growing time because such compounds tend to react more slowly than the soluble fertilizers (Sharpley and Sisak 1997). This effect was also expected with the application of RNF; however, the $\mathrm{P}$ rate added with the use of RNF was smaller than the one applied through poultry litter. Considering the TSP application, its high solubility might have resulted in an increase in $\mathrm{P}$ availability at the early development of the maize crop; however, at the time of the soil sampling, there was no difference in relation to the treatment without fertilization. It should be considered that the soil had sufficient content of $\mathrm{P}$ at the $0-10 \mathrm{~cm}$ depth (Table 1).

Leaf content and uptake of $\mathrm{N}, \mathrm{P}$, and $\mathrm{K}$ by maize landrace plants were not significantly influenced by the interaction between the fertilizers treatments at sowing and topdressing. Organic fertilizer applied during the maize sowing provided better $\mathrm{N}$ leaf content than the treatments without fertilizers and with NK + RNF and NK + TSP fertilization (Table 4). Nitrogen extraction by the shoot of maize was higher after organic fertilization or NK + TSP application than after NK + RNF application or without fertilizers at sowing. Such effects should be regarded as a result of $\mathrm{N} \times \mathrm{P}$ interaction, since $\mathrm{N}$ extraction by the shoot was not significantly different in the treatments without fertilizers or with NK + RNF at sowing. Thus, higher soil $\mathrm{P}$ content provided by the organic fertilizaers and TSP addition might have favored $\mathrm{N}$ uptake by the maize plants. Alves et al. (1999) also observed higher $\mathrm{N}$ accumulation in the shoot of maize when $\mathrm{P}$ and $\mathrm{N}$ were supplied together to all root system. The increase in $\mathrm{P}$ concentration in the maize leaf tissue resulting from the organic fertilization at sowing (Table 4) was followed by the increase in soil $\mathrm{P}$ availability, extracted by Mehlich 1 solution or resin (Table 3). It was observed that exchangeable $\mathrm{K}^{+}$content in the soil was not limiting and the treatments with organic or mineral fertilization at sowing did not exert any influence on the $\mathrm{K}^{+}$content in the soil (Table 3 ) or in the maize leaf tissue (Table 4). On the other hand, $\mathrm{N}$ extraction by the shoot and $\mathrm{N}, \mathrm{P}$ and $\mathrm{K}$ concentrations in the maize leaves were significantly higher with urea application than with organic fertilizer in topdressing (Table 4). Therefore, organic fertilization with poultry litter proved efficient in providing adequate nutrition to maize, when employed to replace the mineral fertilization at sowing, but urea provided a better plant nutrition than the poultry litter fertilization in topdressing.

Table 4 - Leaf content and uptake of N, P, and K by maize landrace plants as affected by fertilizer treatments at sowing and topdressing under a no-till system.

\begin{tabular}{|c|c|c|c|c|c|c|}
\hline \multirow{2}{*}{ Treatment } & \multicolumn{3}{|c|}{ Leaf content } & \multicolumn{3}{|c|}{ Nutrient uptake } \\
\hline & $\mathbf{N}$ & $\mathbf{P}$ & $\mathbf{K}$ & $\mathbf{N}$ & $\mathbf{P}$ & $\mathbf{K}$ \\
\hline & \multicolumn{3}{|c|}{ 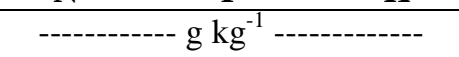 } & \multicolumn{3}{|c|}{------ kg ha ${ }^{-1}$} \\
\hline \multicolumn{7}{|l|}{ Sowing fertilizer } \\
\hline No fertilizer & $25.1 \mathrm{~b}$ & $2.8 \mathrm{~b}$ & 20.9 a & $242.2 \mathrm{~b}$ & $9.5 \mathrm{a}$ & $146.3 \mathrm{a}$ \\
\hline Poultry litter & $28.3 \mathrm{a}$ & $3.4 \mathrm{a}$ & $21.9 \mathrm{a}$ & $337.7 \mathrm{a}$ & $12.3 \mathrm{a}$ & $171.8 \mathrm{a}$ \\
\hline NK + Arad Phosphate Rock & $26.1 \mathrm{ab}$ & $2.9 \mathrm{~b}$ & $21.8 \mathrm{a}$ & $301.0 \mathrm{ab}$ & $9.7 \mathrm{a}$ & $173.8 \mathrm{a}$ \\
\hline NK + Triple Superphosphate & $26.2 \mathrm{ab}$ & $2.9 \mathrm{~b}$ & $20.7 \mathrm{a}$ & $331.8 \mathrm{a}$ & $10.2 \mathrm{a}$ & $188.3 \mathrm{a}$ \\
\hline \multicolumn{7}{|l|}{ Topdressing fertilizer } \\
\hline No fertilizer & $24.2 \mathrm{~b}$ & $2.8 \mathrm{~b}$ & $21.3 \mathrm{ab}$ & $263.8 \mathrm{~b}$ & $11.1 \mathrm{a}$ & $149.7 \mathrm{a}$ \\
\hline Poultry litter & $24.9 \mathrm{~b}$ & $2.9 \mathrm{~b}$ & $20.5 \mathrm{~b}$ & $277.9 \mathrm{~b}$ & $11.4 \mathrm{a}$ & $176.4 \mathrm{a}$ \\
\hline Urea & $32.2 \mathrm{a}$ & $3.7 \mathrm{a}$ & $22.2 \mathrm{a}$ & $367.9 \mathrm{a}$ & $8.8 \mathrm{a}$ & $184.2 \mathrm{a}$ \\
\hline $\mathrm{CV}(\%)$ & 7.7 & 10.7 & 7.1 & 21.9 & 26.7 & 22.7 \\
\hline
\end{tabular}

Same letters in the columns do not differ significantly by Tukey test at $p=0.05$. 
Figure 2 shows correlation data obtained between the soil $\mathrm{P}(0-20 \mathrm{~cm})$ extracted by Mehlich 1 solution and resin and maize landrace leaf $\mathrm{P}$ contents for the treatments with organic fertilizer with poultry litter and mineral fertilizer with $\mathrm{NK}+$ TSP at sowing. Treatments without fertilizers and $\mathrm{NK}+\mathrm{RNF}$ fertilizers at sowing did not result in soil $\mathrm{P}$ changes (Table 3), and, for this reason, were not taken into consideration in this analysis. The increase in soil $\mathrm{P}$ detected by the Mehlich 1 and resin extractants (Table 3) was correlated to $\mathrm{P}$ increase in the maize leaves, when organic fertilizer was surface-applied at sowing (Figure 2). However, when NK + TSP was applied in the sowing furrow, only the extraction with the resin method detected gains in soil $\mathrm{P}$ availability related to increase in $\mathrm{P}$ content in the maize leaves.

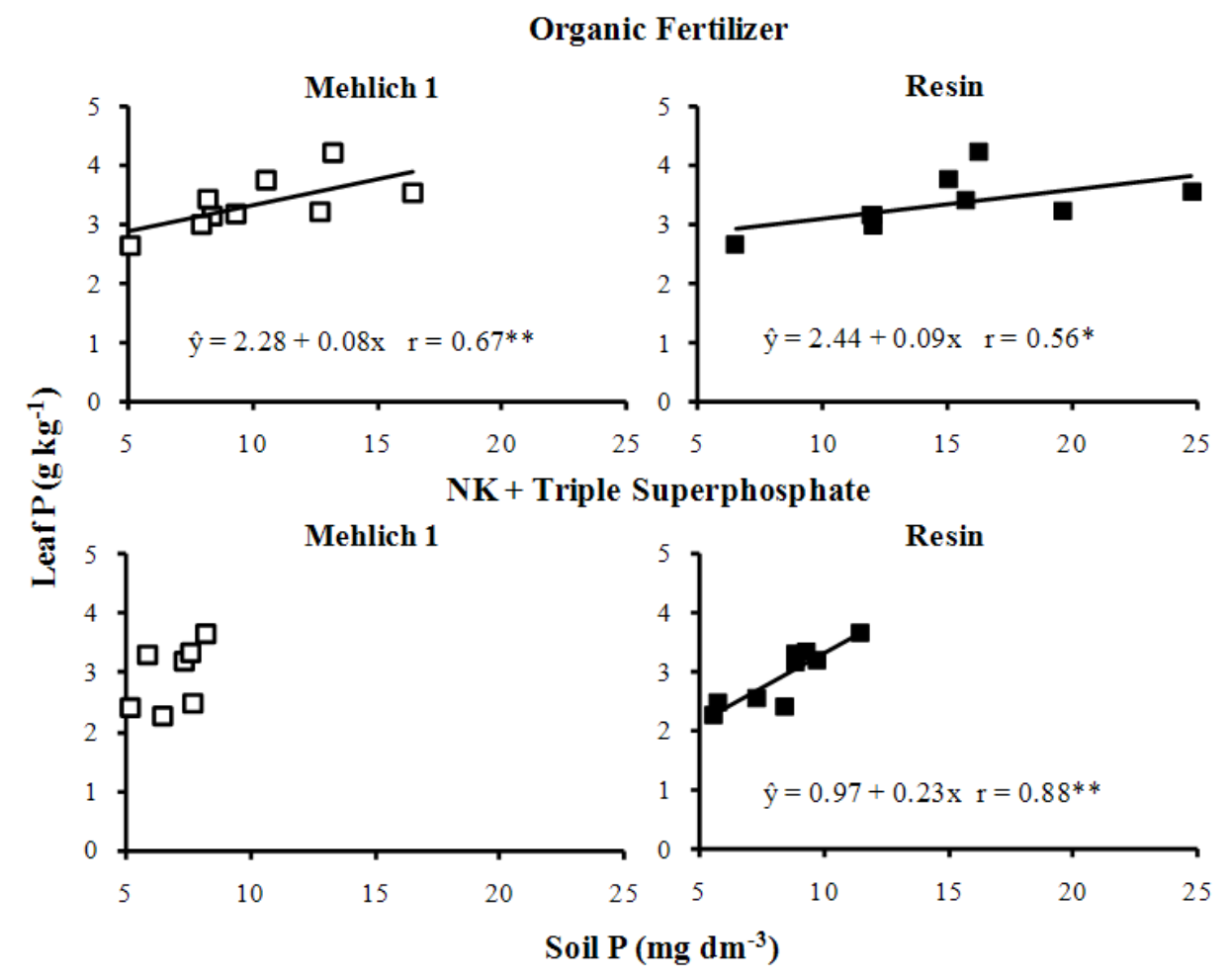

Figure 2 - Relationship between soil P (0-20 cm) extracted by Mehlich 1 solution $(\square)$ and resin (ם) and maize landrace leaf $\mathrm{P}$ contents for the treatments with organic fertilizer with poultry litter and mineral fertilizer with $\mathrm{NK}+$ triple superphosphate at sowing. $*: p<$ 0.05 and $* *: p<0.01$.

Mehlich 1 solution extracts $\mathrm{P}$ bound to $\mathrm{Ca}$ and, in lower proportion, $\mathrm{P}$ bound to $\mathrm{Fe}$ and $\mathrm{Al}$ (Raij 1991). Acid extractants have been criticized, mainly for their capability to solubilize the unavailable $\mathrm{P}$ to the plants in the soils that received natural phosphates application (Moreira and Malavolta 2001). Extraction of soil P by anionic exchange resin presents certain similarities with $\mathrm{P}$ uptake by the plants roots, characterized by labile P transference to the soil solution and from there to the roots (Silva and Raij 1999). Some studies have shown superiority of the resin method in discriminating the available $\mathrm{P}$ in the soils fertilized with natural phosphates (Korndörfer et al. 1999). However, soil $\mathrm{P}$ determination by the resin in these circumstances is also subject to problems resulting from intense soil milling, with disaggregation and particle breakage, jeopardizing the analytical results (Novais and Smyth 1999). In the present study, both the extractants, Mehlich 1 and resin, presented similar efficiency in estimating the available $\mathrm{P}$ after RNF application. That meant that none of the extractants detected changes in soil $\mathrm{P}$ content following RNF application (Table 3), but $\mathrm{P}$ content in the maize leaf tissue was not changed after RNF application (Table 4). A closest relationship between the soil $\mathrm{P}$ and leaf $\mathrm{P}$ contents was obtained with Mehlich 1 
after organic fertilization with poultry litter and with anionic exchange resin after fertilization with TSP (Figure 2).

Chlorophyll content in the leaves (SPAD), dry biomass, height, culm diameter, and lodging of maize landrace plants were not significantly influenced by the interaction between the fertilizers treatments at sowing and topdressing. Chlorophyll reading (SPAD) in the maize leaves (Table 5) showed similar behavior as the $\mathrm{N}$ leaf content (Table 4) to the fertilizers treatments at sowing and topdressing. The highest chlorophyll values in the leaves were obtained with organic fertilization at sowing and urea at topdressing (Table 5). The close correlation $(\mathrm{r}=0.87, p<0.01)$ obtained between the $\mathrm{N}$ content $\left(\hat{y}\right.$, in $\left.\mathrm{g} \mathrm{kg}^{-1}\right)$ and chlorophyll reading ( $x$, in SPAD) in maize landrace leaves $(\hat{y}=-7.88+0.787 x)$ showed the possibility to estimate the $\mathrm{N}$ content in leaf tissue based on the chlorophyllometer reading. The chlorophyll relative content was based on the positive correlation between the chlorophyll and leaf $\mathrm{N}$ levels (Argenta et al. 2001; Rambo et al. 2004), so that the indirect measurement of chlorophyll in the leaves through portable devices in the field might provide valuable information for the management of nitrogen fertilization. NK +
TSP application at sowing resulted in higher maize plants and larger dry biomass production than the treatment without fertilizers, even if the plants height and dry biomass production were similar for all the organic or mineral fertilizers treatments at sowing (Table 5). The plants culm diameter was larger in the treatments with organic or mineral fertilizers at sowing than in the treatment without the fertilizers. Regarding topdressing fertilization, the use of urea resulted in plants with increased height and larger dry biomass production than the treatment without fertilizers and plants with larger culm diameter than the treatment with organic fertilizer. The dry biomass production in the treatment with poultry litter application at topdressing was similar to the treatment without topdressing. Improvement in the plant nutrition caused by the fertilizers at sowing resulted in more vigorous plants resistant to lodging, taking into consideration that the highest percentage of lodged plants was obtained in the treatment without fertilization at sowing. The elevated percentage of lodged maize plants in the present study was a result of the high height of the landrace variety associated with the occurrence of winds in the region.

Table 5 - Chlorophyll content in leaves (SPAD), dry biomass, height, culm diameter and lodging of maize landrace plants as affected by fertilizer treatments at sowing and topdressing under a no-till system.

\begin{tabular}{|c|c|c|c|c|c|}
\hline Treatment & $\begin{array}{l}\text { Chlorophyll } \\
\text { (SPAD) }\end{array}$ & $\begin{array}{c}\text { Dry } \\
\text { biomass }\end{array}$ & $\begin{array}{l}\text { Plant } \\
\text { height }\end{array}$ & $\begin{array}{c}\text { Culm } \\
\text { diameter }\end{array}$ & $\begin{array}{c}\text { Lodged } \\
\text { plants }\end{array}$ \\
\hline & & $\mathrm{kg} \mathrm{ha}^{-1}$ & ---------- & -------- & $\%$ \\
\hline \multicolumn{6}{|l|}{ Sowing fertilizer } \\
\hline No fertilizer & $42.0 \mathrm{~b}$ & $9567.3 \mathrm{~b}$ & $2.9 \mathrm{~b}$ & $0.021 \mathrm{~b}$ & $69.7 \mathrm{a}$ \\
\hline Poultry litter & $45.3 \mathrm{a}$ & $12044.7 \mathrm{ab}$ & $3.0 \mathrm{ab}$ & $0.023 \mathrm{a}$ & $60.0 \mathrm{ab}$ \\
\hline NK + Arad Phosphate Rock & $44.0 \mathrm{ab}$ & $11150.6 \mathrm{ab}$ & $3.0 \mathrm{ab}$ & $0.023 \mathrm{a}$ & $52.6 \mathrm{~b}$ \\
\hline NK + Triple Superphosphate & $44.0 \mathrm{ab}$ & $12462.4 \mathrm{a}$ & $3.1 \mathrm{a}$ & $0.023 \mathrm{a}$ & $59.5 \mathrm{ab}$ \\
\hline \multicolumn{6}{|l|}{ Topdressing fertilizer } \\
\hline No fertilizer & $41.5 \mathrm{~b}$ & $10888.3 \mathrm{a}$ & $2.9 \mathrm{~b}$ & $0.022 \mathrm{ab}$ & $56.1 \mathrm{a}$ \\
\hline Poultry litter & $42.2 \mathrm{~b}$ & $10848.5 \mathrm{a}$ & $3.0 \mathrm{ab}$ & $0.021 \mathrm{~b}$ & $61.5 \mathrm{a}$ \\
\hline Urea & $47.8 \mathrm{a}$ & $12281.9 \mathrm{~b}$ & $3.1 \mathrm{a}$ & $0.023 \mathrm{a}$ & $63.8 \mathrm{a}$ \\
\hline $\mathrm{CV}(\%)$ & 3.9 & 12.7 & 5.0 & 7.6 & 16.0 \\
\hline
\end{tabular}

Same letters in the columns do not differ significantly by Tukey test at $p=0.05$.

Maize grain yields were significantly influenced by the interaction between the fertilizers treatments at sowing and topdressing (Fig. 3 and 4). When there was no topdressing fertilization, organic fertilization with poultry litter resulted in a higher maize yield than the treatment without fertilization at sowing (Fig. 3). Maize yield was higher with poultry litter or NK + RNF and NK +
TSP in relation to the treatment without fertilization at sowing, when poultry litter was applied at topdressing (Fig. 3). Fertilization with $\mathrm{NK}+\mathrm{TSP}$ resulted in a higher maize yield than the treatment without fertilization at sowing, when urea was used at topdressing (Fig. 3). Topdressing fertilization, both poultry litter and with urea, did not change maize yield in the absence of 
fertilization at sowing (Fig. 4). Urea application provided a higher maize yield than topdressing poultry litter fertilization, when fertilization at sowing was poultry litter or with NK + RNF and NK + TSP (Fig. 4). Results revealed that in order to obtain higher maize landrace yield, fertilization at sowing could either be organic with poultry litter or mineral with NK + RNF or NK + TSP, but topdressing fertilization should be with urea.
Poultry litter application at topdressing showed low efficiency for the maize production, with similar effect to treatment without topdressing. Because the mineralization of organic $\mathrm{N}$ of the poultry litter occurs over time after application (Yadvinder-Singh et al. 2009), the utilization of N from poultry litter by maize crop is increased with the previous application at sowing.
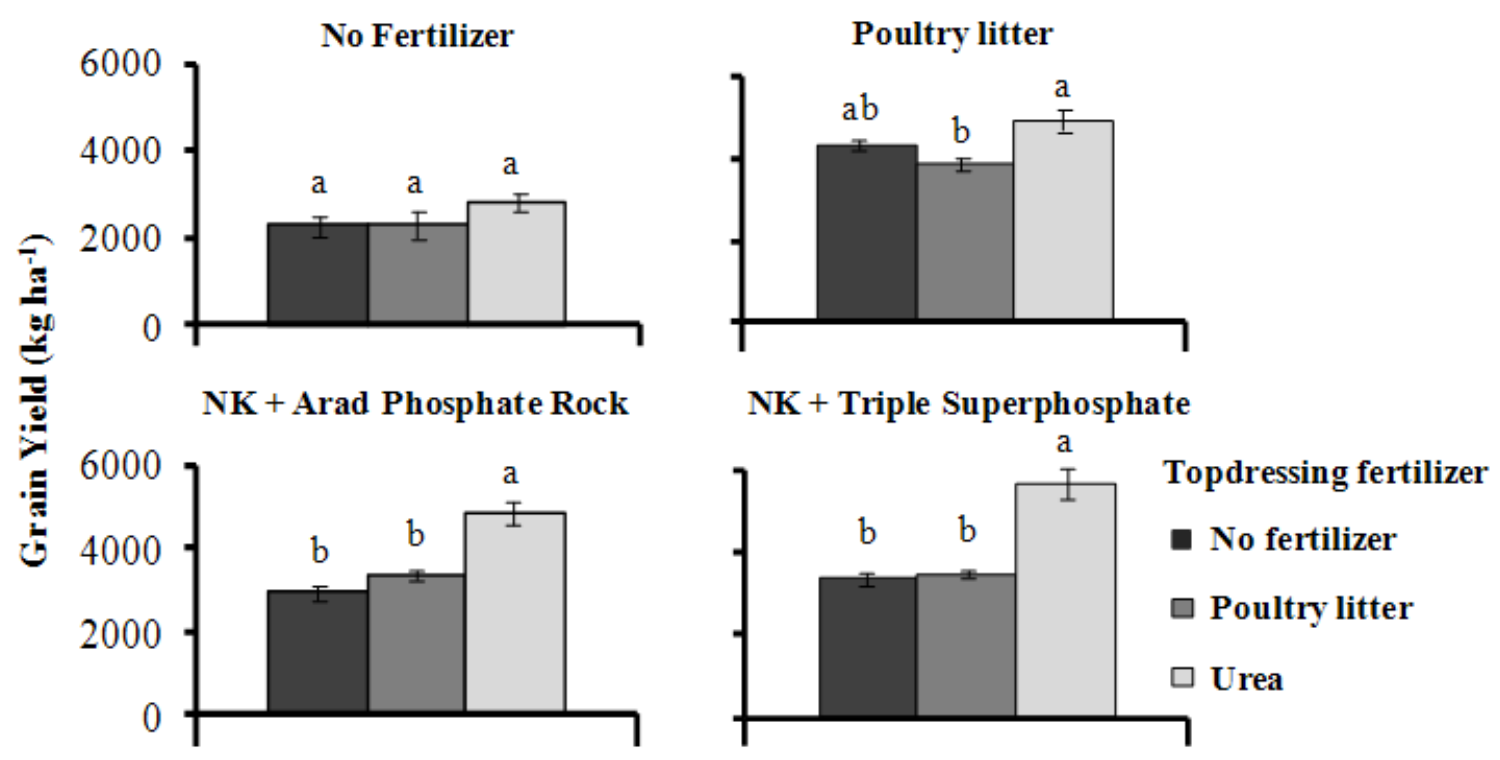

Figure 3 - Grain yield of maize landrace as affected by treatments without fertilizer and with poultry litter, NK + Arad phosphate rock, and NK + triple superphosphate at sowing, considering the treatments without fertilizer and with poultry litter, and urea at topdressing. Same letters do not differ significantly by Tukey test at $p=0.05$. Vertical bars indicate standard deviation of the mean.

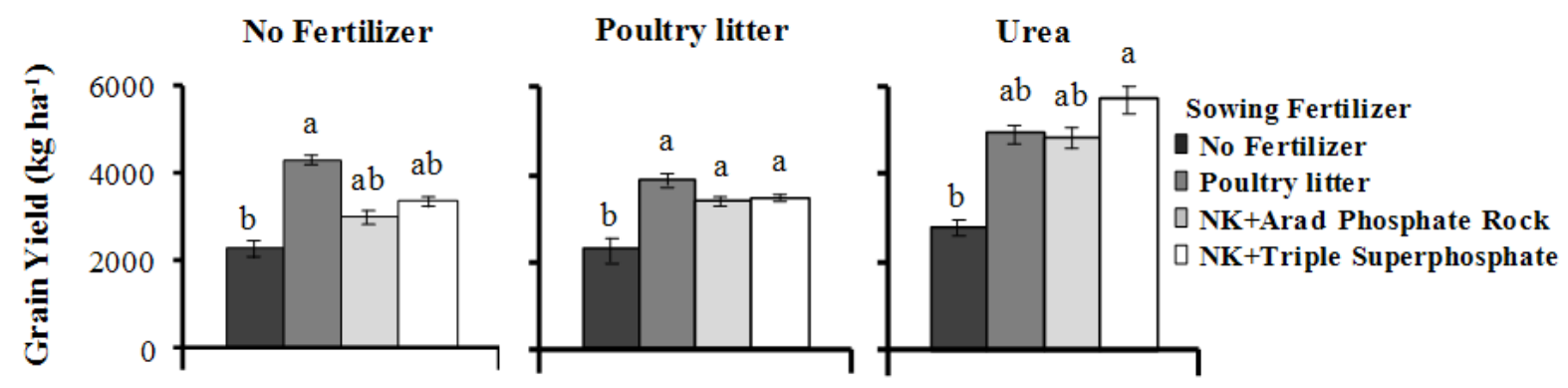

Figure 4 - Grain yield of maize landrace as affected by treatments without fertilizer and with poultry litter, and urea at topdressing, considering the treatments without fertilizer and with poultry litter, NK + Arad phosphate rock, and NK + triple superphosphate at sowing. Same letters do not differ significantly by Tukey test at $p=0.05$. Vertical bars indicate standard deviation of the mean. 


\section{CONCLUSIONS}

Organic fertilization with poultry litter on the surface at sowing of maize landrace under a no-till system resulted in higher available $\mathrm{P}$ in the soil surface layer than $\mathrm{NK}+$ reactive natural phosphate from Arad and NK + triple superphosphate in the sowing furrow. For maize landrace production under a no-till system, mineral fertilization in the sowing furrow could be replaced by organic fertilization with poultry litter on the surface. However, topdressing fertilization with urea provided better plant $\mathrm{N}$ nutrition and higher grain yield, therefore it is not advisable to replace it by organic fertilization with poultry litter.

\section{ACKNOWLEDGEMENTS}

Authors thank to the FINEP and FUNDAÇÃO ARAUCÁRIA for financial support to the research project BIOAGROPAR: Bioprospecting and technology for development of the maize landrace production chain.

\section{REFERENCES}

Alves VMC, Magalhães JV, Vasconcelos CA, Novais RF, Bahia Filho AFC, França GE, et al. Acúmulo de nitrogênio e de fósforo em plantas de milho afetadas pelo suprimento parcial de fósforo às raízes. $R$ Bras Ci Solo. 1999; 23: 299-305.

Argenta G, Silva PRFda, Bortolini CG. Teor de clorofila na folha como indicador do nível de $\mathrm{N}$ em cereais. Ci Rural. 2001; 31: 715-722.

Chien SH, Menon RG. Factors affecting the agronomic effectiveness of phosphate rock for direct application. Fert Res. 1995; 41: 227-234.

Comissão de Química e Fertilidade do Solo RS/SC CQFS-RS/SC. Manual de adubação e de calagem para o Estado do Rio Grande do Sul e Santa Catarina. Porto Alegre: SBCS/Núcleo Regional Sul; 2004.

Derpsch R, Friedrich T. Global overview of conservation agriculture adoption. In: IV World Congress on Conservation Agriculture: Proceedings: Lead Papers; 2009 Feb; New Delhi, India. New Delhi: Indian Council of Agricultural Research: ICAR; 2009. p. 429-438.

Endale DM, Schomberg HH, Fisher DS, Jenkins MB, Sharpe RR, Cabrera ML. No-Till corn productivity in a southeastern United States Ultisol amended with poultry litter. Agron J. 2008; 100: 1401-1408.
Fordhan AW, Schwertmann U. Composition and reaction of liquid manure (gülle), with particular reference to phosphate - II: Solid phase components. J Environ Qual. 1977; 6: 136-140.

Hobbs PR, Sayre K, Gupta R. The role of conservation agriculture in sustainable agriculture. Philos T Roy Soc B. 2008; 363: 543-555.

Kiehl EJ. Fertilizantes orgânicos. Piracicaba: Ceres; 1985.

Korndörfer GH, Lara-Cabezas WA, Horowitz N. Eficiência agronômica de fosfatos naturais reativos na cultura do milho. Sci Agric. 2009; 56: 399-404.

Lal R. Sustainable management of soil resources in the humid tropics. Tokyo: The United Nations University; 1995.

Machado CTT, Guerra JGM, Almeida DL, Machado A T. Variabilidade entre genótipos de milho para eficiência no uso de fósforo. Bragantia. 1999; 58: 109-124.

Malavolta E, Vitti GC, Oliveira SA. Avaliação do estado nutricional das plantas: princípios e aplicações. $2^{a}$ ed. Piracicaba: Potafós; 1997.

Moore PA, Daniel TC, Edwards DR. Effect of chemical amendments on ammonia volatilization from poultry litter. J Environ Qual. 1995; 24: 293-300.

Moreira A, Malavolta E. Fontes, doses e extratores de fósforo em alfafa e centrosema. Pesq Agropec Bras. 2001; 36: 1519-1527.

Novais RF, Smyth TJ. Fósforo em solo e planta em condições tropicais. Viçosa: Universidade Federal de Viçosa; 1999.

Paterniani E. Melhoramento e produção de milho no Brasil. Piracicaba: Fundação Cargill; 1980.

Paterniani E, Nass LL, Santos MX. O valor dos recursos genéticos de milho para o Brasil: uma abordagem histórica da utilização do germoplasma. In: Udry $\mathrm{CV}$, Duarte $\mathrm{W}$, editors. Uma história brasileira do milho: o valor dos recursos genéticos. Brasília: Paralelo 15; 2000. p. 11-41.

Pauletti V, Serrat BM, Motta ACV, Favaretto N, Anjos A. Yield response to fertilization strategies in notillage soybean, corn and common bean crops. Braz Arch Biol Technol. 2010; 53: 563-574.

Pavan MA, Bloch MF, Zempulsky HC, Miyazawa M, Zocoler DC. Manual de análise química do solo e controle de qualidade. Londrina: Instituto Agronômico do Paraná; 1992.

Pinto ATB, Pereira J, Oliveira TR, Prestes RA, Mattielo RR, Demiate IM. Characterization of corn landraces planted grown in the Campos Gerais region (Parana, Brazil) for industrial utilization. Braz Arch Biol Technol. 2009; 52: 17-28.

Prochnow LI, Quispe JFS, Francisco EAB, Braga G. Effectiveness of phosphate fertilizers of different water solubilities in relation to soil phosphorus adsorption. Sci Agric. 2006; 63: 333-340. 
Rambo L, Silva PRF, Argenta G, Sangoi L. Parâmetros de planta para aprimorar o manejo da adubação nitrogenada de cobertura em milho. Ci Rural. 2004; 34: 1637-1645.

Sharpley AN, Sisak I. Differential availibility of manure and inorganic sources of phosphorus in soil. Soil Sci Soc Am J. 1997; 61: 1503-1508.

Silva FC, Raij B van. Disponibilidade de fósforo em solos avaliada por diferentes extratores. Pesq Agropec Bras. 1999; 34: 267-288.

Raij B van. Fertilidade do solo e adubação. São Paulo: Ceres; 1991.
Raij B van, Andrade JC, Cantarella H, Quaggio JA. Análise química para avaliação da fertilidade de solos tropicais. Campinas: Instituto Agronômico; 2001.

Yadvinder-Singh, Gupta RK, Thind HS, Bijay-Singh, Varinderpal-Singh, Gurpreet-Singh, et al. Poultry litter as a nitrogen and phosphorous source for the rice-wheat cropping system. Biol Fert Soils. 2009; 45: 701-710.

Received: December 12, 2010; Revised: February 18, 2011; Accepted: August 26, 2011. 